\title{
Vietnam's Response to the COVID-19 Outbreak
}

\section{Sanja Ivic ${ }^{1,2}$ (D)}

Received: 21 May 2020 / Revised: 20 June 2020 / Accepted: 22 June 2020 /

Published online: 10 July 2020

C National University of Singapore and Springer Nature Singapore Pte Ltd. 2020

\begin{abstract}
This article explores Vietnam's response to the COVID-19 pandemic as an example of good ethical practice in dealing with the COVID-19 outbreak. Vietnam's response to the pandemic is in accordance with the ethics of care which emphasizes solidarity and responsibility. Vietnam's approach to the COVID-19 pandemic is also in accordance with the third generation of human rights that promote solidarity and responsibilities towards the community. A full implementation of human rights requires more emphasis on responsibilities, especially in the time of crisis.
\end{abstract}

Keywords Vietnam $\cdot$ COVID-19 $\cdot$ Care $\cdot$ Solidarity $\cdot$ Rhetoric

\section{Introduction}

This article analyzes Vietnam's response to the COVID-19 pandemic crisis as an example of good ethical practice in dealing with the COVID-19 outbreak. It also investigates what lessons might be learned from Vietnam's response for future pandemics. Vietnam has a border with China, where the outbreak of the coronavirus was first detected. Vietnam has a population of over 95 million people. However, Vietnam's Ministry of Health reported only just over 300 cases of COVID-19 by 20 May 2020 and not a single death. Assuming these data are accurate, Vietnam's approach to the pandemic crisis offers significant insights (Le 2020). Vietnam's response to the pandemic was successful as it included early measures, Vietnamese leadership started using war rhetoric regarding the COVID-19 and called on the citizens to unite, points of entry have been firmly controlled, epidemic control groups carried out contact tracing and testing, "localized centers for disease control and preventive health facilities are

Sanja Ivic

sanjaivic@tdtu.edu.vn

1 Department for Management of Science and Technology Development, Ton Duc Thang University, Ho Chi Minh City, Vietnam

2 Faculty of Social Sciences and Humanities, Ton Duc Thang University, Ho Chi Minh City, Vietnam 
closely collaborating with hospitals in case detection, isolation and treatment", citizens were well informed of protective measures, the private sector gave its support, and so forth (Le 2020).

\section{A strategy for increasing solidarity and care}

Precautionary measures in Vietnam were implemented more than a month before COVID-19 global pandemic was declared by the World Health Organization (Le 2020). "Early, decisive and transparent actions by the country's leadership, along with the engagement and solidarity of citizens, have been a key to Vietnam's success in combating COVID-19 to date" (Le 2020). This strategy aimed at increasing solidarity and care for oneself and others. The Government of Vietnam employed the war rhetoric from the beginning of the pandemic and emphasized solidarity in combating the pandemic. "In Vietnam, the news coverage has been marked by a prominent narrative: "Every citizen is a soldier fighting the disease"" (Tran 2020).

The Prime Minister of Vietnam, Nguyen Xuan Phuc, represented the pandemic as a battle and called on the citizens to unite (Le Thu 2020). The COVID-19 pandemic was represented as an enemy in Vietnam's public political discourse. Social distancing and washing one's hands were portrayed as a matter of patriotism, and this message was also communicated through popular art and information campaigns (Le Thu 2020). A viral propaganda poster created by artist Hiep Le Duc communicated the message "to stay home is to love your country" (Tran 2020).

The Prime Minister of Vietnam Nguyen Xuan Phuc said "Every business, every citizen, every residential area must be a fortress to prevent the epidemic" (Pham 2020). According to surveys, 62\% of citizens of Vietnam said that they agree with the government's response to the COVID-19 pandemic (Pham 2020). Some authors have warned that war is not the right metaphor for the response to the pandemic. According to Hagstrom, "not only does war lead us to look for enemies and scapegoats, war solutions are directed from the top rather than resourced from local communities" (Hagstrom 2020). However, the metaphor of war employed in the Vietnamese public discourse did not lead to looking for scapegoats and solutions that did not include local communities. It contributed to increasing solidarity in Vietnamese society, which was advocated by political leaders in combating COVID-19. Staying at home and washing one's hands became a matter of patriotism in Vietnam (Walden 2020). "Philanthropists have installed 'rice ATMs' to feed vulnerable people amid an economic slowdown" (Le 2020).

The president of the USA Donald Trump was criticized for declaring himself a "wartime president" and arguing that the USA has a "clear battle plan" (Hagstrom 2020). However, the citizens of Vietnam accepted their government's war rhetoric. "Here, the reference to war calls to mind a story of resourcefulness deep-rooted in the country's identity. As early as January [2020], a BBC News article (Phuc 2020) arguing how Vietnam's weak health care system and low budget necessitates a rapid collective response and strict quarantining made its rounds on social media" (Tran 2020). This strategy made social distancing measures very successful. 


\section{The ethics of social distancing}

Some authors argue that the ethics of social distancing is based on altruism (Brakman 2020). In the Cambridge Dictionary, altruism is defined "as willingness to do things that bring advantages to others" and often embrace personal sacrifices. According to Brakman, "rooting social distancing in altruism isn't as robust a motivation (...) as framing it as an ethical duty" (Brakman 2020). Social distancing relates to the right of life defined by Article 3 of the Universal Declaration of Human Rights (1948). This article states: "Everyone has the right to life, liberty and security of person" (UN General Assembly 1948). Social distancing also relates to the right to security of person. Thus, it should not be perceived as an optional behavior based on altruism and kindness (Brakman 2020). It should be understood as an act of duty based on the ethics of care, which emphasizes commitment to vulnerable and marginalized. The ethics of care entails the web of relationships, which is motivated by a shared belonging to humanity (Gilligan 1982). In light of ethics of care, the requirement for practicing social distancing for the good of vulnerable groups (elderly, ill, and so forth) represents the social responsibility towards our shared communities. Some social groups such as disabled persons, homeless, undocumented migrants, and so forth require special attention (Lewnard and Lo 2020).

Social distancing is also perceived as rooted in self-interest (Brakman 2020). However, such points of view "fail to get at the interconnected nature of the problem" of the COVID-19 pandemic (Brakman 2020). Brakman (2020) argues that solidarity should represent the foundation of social distancing (not altruism or self-interest). According to Ali, a paradigm shift "from social isolation to social solidarity" is necessary (Ali 2020). The language of social isolation does not contribute to the physical and mental health of the vulnerable (since they are usually members of marginalized social groups), and therefore, the language of solidarity is more appropriate in response to the pandemic crisis (Ali 2020). Nevertheless, this point of view is also too narrow. Solidarity, as an ethical value, is "not sufficient to guarantee equal access to health care for the whole population" (Made et al. 2001, 231). Solidarity should be enriched with other ethical values such as care and responsibility, to make the social distancing process successful during the pandemic. Thus, the ethics of care should represent the foundation of social distancing. This point of view reminds us that we all share the same humanity. It also speaks to reorientation of individual rights to collective rights and the common good. "By grounding social distancing in an ethical posture, we don't just increase the likelihood of buy-in to deal with the present crisis we cultivate a virtue that ensures we'll stay the course" (Brakman 2020).

The ethics of care was first articulated around 40 years ago, but it is still not clearly defined, and there are many disagreements about its foundations and role. Although the ethics of care stems from feminist theory, its application is much wider. According to Carol Gilligan: "In this conception, the moral problem arises from conflicting responsibilities rather than from competing rights and requires for its resolution a mode of thinking that is contextual and narrative rather than formal and abstract. This conception of morality as concerned with the activity of care centers moral development around the understanding of responsibility and relationships, just as the conception of morality as fairness ties moral development to understanding of rights and rules" (Gilligan 1982, 19). 
Vietnam's response to the COVID-19 outbreak is in accordance with ethics of care which emphasizes solidarity and relationships. Toan Luu Duc Huynh (2020) emphasizes:

This is the first time since the unification after the Vietnam War that the whole Vietnamese community, including military, scholars, businessmen, and many different classes in our society, have participated in different types of contributions. (...) The soldiers are encouraged to become public servants to supervise those who come back from the epidemic areas in quarantine areas. The businessmen are raising the movement to donate lands and provide financial incentives to fight against the COVID-19 outbreaks. (...) What we are learning from the event is the importance of our country's unity. Therefore, according to the international survey conducted by the 12 different institutions, including Harvard, Cambridge, IESE, and Warwick University, Vietnam is ranked the second position that participants trust their country's government to take care of its citizens.

The "Saint John Bosco" Province of Vietnam advocated the "Ban COVID-19" campaign, which was very successful as it collected donations to help 7300 vulnerable persons (Agenzia iNfo Salesiana 2020). This solidarity campaign lasted 4 weeks. Besides helping the most vulnerable, it has enabled the creation of closer relationship between neighboring communities (Agenzia iNfo Salesiana 2020). There are many other examples across Vietnam, such as creating the rice ATMs and involvement of private sector in dealing with the pandemic (Le 2020). "This signals a commitment to responsibility rather than rights, the collective social group rather than the individual, an ethics based on caring rather than the supposedly impartial individual reason of the Kantian moral agent" (Himma and Tavani 2008, 591). The ethics of care discourse is present in the Vietnamese government's response to the pandemic crisis. The Prime Minister of Vietnam said: "Alongside efforts to deal with the far-reaching consequences of the epidemic, countries need to devise a post-COVID-19 development plan, with a primary focus on supporting businesses in restoring production and maintaining social security for the people, especially those of vulnerable groups, to ensure no one is left behind" (Ngyjen 2020).

Advocating the ethics of care is closely linked to the creation of a new concept of citizenship, which overcomes the traditional definition of citizenship as an independent category which implies that the citizen is neither a giver nor a receiver of care (Young 1990). The new concept of citizenship includes a moral obligation to care for the vulnerable - citizenship is defined as caring practice. This concept is in line with the third generation of human rights ${ }^{1}$ based on solidarity and collective rights.

The third generation of human rights is ascribed to social groups, communities, and nations. Jack Donnelly (1989) objects to the third generation of human rights and argues that the nature of human rights is individual. Some authors argue that collective nature of the third generation of human rights could "provide a 'justification' for certain repressive regimes to deny (individual) human rights in the name of these collective

\footnotetext{
${ }^{1}$ The first generation of human rights includes civil and political rights, while the second generation of human rights includes economic, social, and cultural rights.
} 
human rights; for example, severely curtailing civil rights in order to secure 'economic development"' (Council of Europe 2017).

Vietnam's response to the COVID-19 is in accordance with the third generation of human rights that are based on solidarity. The nature of the third generation of human rights is collective (Ivic 2010). These rights include the following: right to development, right to a healthy environment, right to peace, right to benefit from the common heritage of mankind, and right to humanitarian assistance.

In Asia, the duties of the individual to the community (collective rights) have priority over individual rights. "At the basis of this argument are claims of cultural difference: Asians, especially those influenced by Confucianism, are said to value the community over the individual, to strive for consensus and to respect an authority that takes care of its citizens" (Brems 2001, 86). ${ }^{2}$ Within this point of view, individuals are, first of all, perceived as members of a certain group (family, society, or nation). From this point of view, a legal basis can be found for the restriction of individual freedoms, if it contributes to the preservation of collective health and the realization of the right to life. However, this is a rather thin view of Confucianism, which fails to identify different forms and versions of Confucianism (see Son 2016).

Vietnamese society reflects the core values of Confucianism. ${ }^{3}$ These values embrace concepts of social obligation, freedom, and political organization that are quite different from Western liberal understanding of these concepts (Nghia 2005, 42). These values also include collectivism, respect for elderly, respect for authority, loyalty, social harmony, and so forth. Confucianism influences Vietnam's culture, society, politics, economy, and philosophy (Truong et al. 2016).

Chinese experts suggested that "in the conflict of social health interests versus individual privileges, the government should always prioritize life and health rights and protect human rights to the highest extent" (Hu 2020). Confucian perspective allows prioritizing life and health rights over civil liberties. According to Peter Peverelli (2020), these measures based on priority of collective human rights over individual human rights work well in Asian "communitarian cultural context". However, they do not work well in Western liberal democracies which emphasize individual rights and freedoms. The modern idea of human rights is based on the idea of universality of human nature. Western understanding of human rights gives priority of individuality over collectivity and promotes liberal values, while the Eastern conception of human rights gives priority to collective rights over individual rights. According to Peverelli (2020): "Each nation deals with the local situation in a way that suits the national or local culture. However, these differences are also causing heated debate about 'the best way' of coping with a new contagious disease like this. That debate is not always conducted with respect for other nation's values".

Moreover, Western conception of human rights emphasizes human dignity, which is often criticized by non-Western authors. For instance, "Yasuaki Onuma criticizes this term, pointing out that 'dignity' has been itself a favorite term in the same Western philosophical stream that has elaborated human rights. He prefers to speak of the 'pursuit of spiritual as well as material well-being' as the universal' (Taylor 1996, 2).

\footnotetext{
${ }^{2}$ However, some authors emphasize that individualist aspirations exist both within Buddhism and Confucianism (Brems 2001, 87).

${ }^{3}$ However, Vietnamese society is also influenced by Taoism, Buddhism, and Western civilization.
} 
As it is already mentioned, Western idea of human rights is based on philosophy that gives primacy to the individual, while non-Western give primacy to the community. Nevertheless, Western understanding of human rights does not exclude collective rights, and Eastern conception of human rights does not exclude individual rights (Son 2016).

According to Sikkink (2020), "balancing of rights is foreseen in the Universal Declaration of Human Rights (UDHR), which speaks of limiting rights to 'respect the rights and freedoms of others.' The UDHR goes further, however, and recognizes that each of us has 'duties to the community', and its preamble calls on all of us to promote rights (...) To protect our collective right to health, we may need to recognize that we have a right to freedom of movement, but also a responsibility not to travel in certain circumstances; a right to education, but a responsibility to accept that it may be suspended temporarily or delivered on-line". Thus, a full implementation of human rights requires more emphasis on responsibilities of all actors, especially in the time of crisis (Sikkink 2020).

\section{Conclusion}

There is not a single confirmed fatality from COVID-19 in Vietnam, and there are many lessons that can be learned from this country's response to the pandemic crisis. Early measures along with the solidarity of citizens and care for the vulnerable social groups have been the key of Vietnam's successful response to the COVID-19 outbreak. Vietnam's response to the COVID-19 emphasizes care and solidarity and is in accordance with the ethics of care. The concrete examples of the ethics of care in the specific response of Vietnam to the COVID-19 outbreak are reflected in care for the vulnerable social groups and maintaining social security as well as security of person. The ethics of care overcomes binary oppositions: we/they, young/old, public/private, wealthy/poor, citizen/stranger, and so forth; and this point of view is reflected in Vietnam's response to the COVID-19 pandemic.

\section{References}

Agenzia iNfo Salesiana. 2020. Vietnam - double Vietnamese "miracle" against Covid-19: Prevention and solidarity. Agenzia iNfo Salesiana, 11 June 2020. https://www.infoans.org/en/sections/news/item/10592vietnam-double-vietnamese-miracle-against-covid-19-prevention-and-solidarity.

Ali, Afroz. 2020. We need a paradigm shift from social isolation to social solidarity. ABC, 31 March 2020. https://www.abc.net.au/religion/paradigm-shift-from-social-distancing-to-social-solidarity/12106530.

Brakman, Sarah-Vaughan. 2020. Social distancing isn't a personal choice. It's an ethical duty. Vox, 9 April 2020. https://www.vox.com/future-perfect/2020/4/9/21213425/coronavirus-covid-19-social-distancingsolidarity-ethics.

Brems, Eva. 2001. Human rights: Universality and diversity. The Hague: Martinus Nijhoff Publishers.

Council of Europe. 2017. The evolution of human rights. https://www.coe.int/en/web/compass/the-evolutionof-human-rights. Accessed 6 July 2020.

Donnelly, Jack. 1989. Universal human rights in theory and practice. Ithaca: Cornell University Press.

Gilligan, Carol. 1982. In a different voice: Psychological theory and women's development. Cambridge, MA: Harvard University Press.

Hagstrom, Jacob. 2020. Stop calling Covid-19 a war. Washington Post, 20 April 2020. https:/www. washingtonpost.com/outlook/2020/04/20/stop-calling-covid-19-war/. 
Himma, Kenneth E., and Herman T. Tavani, eds. 2008. The handbook on information and computer ethics. Hoboken: Wiley.

Hu, Yuwei. 2020. Prioritizing human rights helps China defeat Covid-19: Experts. Global Times, 11 May 2020. https://www.globaltimes.cn/content/1188066.shtml.

Huynh, Toan Luu Duc. 2020. The Covid-19 containment in Vietnam: What are we doing? Journal of Global Health 10 (1):010338. https://doi.org/10.7189/jogh.10.010338.

Ivic, Sanja. 2010. Dynamic nature of human rights: Rawls's critique of moral universalism. Trans/Form/Asão 33(2): 223-240. https://doi.org/10.1590/S0101-31732010000200013.

Le, Sang Minh. 2020. Containing the coronavirus (Covid-19): Lessons from Vietnam. World Bank Blogs, 30 April 2020. https://blogs.worldbank.org/health/containing-coronavirus-covid-19-lessons-vietnam.

Le Thu, Huong. 2020. Vietnam's successful battle against Covid-19. Council of Foreign Relations, 30 April 2020. https://www.cfr.org/blog/vietnams-successful-battle-against-covid-19. Accessed 15 May 2020.

Lewnard, Joseph A., and Nathan C. Lo. 2020. Scientific and ethical basis for social-distancing interventions against COVID-19. Lancet Infectious Diseases 20(6): 631-633. https://doi.org/10.1016/S1473-3099(20 )30190-0.

van der Made, Jan, Ruud ter Meulen, and Masja van den Burg. 2001. Solidarity and care in the Netherlands. In Health and social care in Europe, ed. Ruud ter Meulen, Wil Arts, and Ruud Muffels, 229-253. Dordrecht: Kluwer Academic Publishers.

Nghia, Pham Duy. 2005. Confucianism and the conception of the law in Vietnam. In Asian socialism and legal change: The dynamics of Vietnamese and Chinese reform, ed. Gillespie John and Nicholson Pip, 76-90. Canberra: ANU Press.

Ngyjen, Hannah. 2020. Vietnamese PM urges countries to further enhance solidarity amid Covid-19. Vietnam Times, 20 May 2020. https://vietnamtimes.org.vn/vietnamese-pm-urges-countries-to-further-enhancesolidarity-amid-covid-19-20470.html.

Peverelli, Peter J. 2020. Coronavirus pandemic: Human rights conference underway in Chongqing [Video]. China Human Rights, 11 May 2020. http://www.chinahumanrights.org/html/2020/REVIEW_0511/1316. html.

Pham, Linh. 2020. Why does Vietnam gain international praise for fight against Covid-19? Hanoi Times, 10 April 2020. http://hanoitimes.vn/why-does-vietnam-gain-international-praise-for-fight-against-covid-19311680.html. Accessed 15 May 2020.

Phuc, Hoang Kim. 2020. 2019-nCov: Vietnam needs a quarantine model so that health does not collapse if the disease spreads. BBC News, 30 January 2020. https://www.bbc.com/vietnamese/forum-51308406.

Sikkink, Kathryn. 2020. Rights and responsibilities in the coronavirus pandemic. Open Global Rights, updated 30 March 2020. https:/www.openglobalrights.org/rights-and-responsibilities-in-the-coronaviruspandemic/.

Son, Bui Ngoc. 2016. Confucian constitutionalism in East Asia. London: Routledge.

Taylor, Charles. 1996. Conditions of an unforced consensus on human rights. A paper delivered at the second workshop in Bankok, sponsored by The Carnegie Council on Ethics and International Affairs. http:/www.iilj.org/wp-content/uploads/2016/08/Taylor-Conditions-of-an-Unforced-Consensus-onHuman-Rights-1996.pdf. Accessed 6 July 2020.

Tran, Jueni Duyen. 2020. Vietnam's war on Covid-19. Journal of International Affairs, 12 May 2020. https://jia.sipa.columbia.edu/online-articles/vietnam\%E2\%80\%99s-war-covid-19. Accessed 15 May 2020.

Truong, Thang Dinh, Philip Hallinger, and Kabini Sanga. 2016. Confucian values and school leadership in Vietnam: Exploring the influence of culture on principal decision making. Educational Management Administration \& Leadership 45 (1): 77-100. https://doi.org/10.1177/1741143215607877.

UN General Assembly. 1948. Universal declaration of human rights. Adopted and proclaimed by General Assembly resolution 217 A (III) of 10 December 1948. https://www.un.org/en/universal-declarationhuman-rights/. Accessed 4 June 2020.

Walden, Max. 2020. How has Vietnam, a developing nation in South-East Asia, done so well to combat coronavirus? ABC News, 13 May 2020. https://www.abc.net.au/news/2020-05-13/coronavirus-vietnamno-deaths-success-in-south-east-asia/12237314.

Young, Iris Marion. 1990. Justice and the politics of difference. Princeton: Princeton University Press.

Publisher's Note Springer Nature remains neutral with regard to jurisdictional claims in published maps and institutional affiliations. 